\title{
Deliberate about, not in, Elections
}

\section{Citation}

Thompson, Dennis F. 2013. Deliberate about, not in, Elections. Election Law Journal 12 (4): 372385.

\section{Published Version}

10.1089/elj.2013.0194

\section{Permanent link}

http://nrs.harvard.edu/urn-3:HUL.InstRepos:37093187

\section{Terms of Use}

This article was downloaded from Harvard University's DASH repository, and is made available under the terms and conditions applicable to Open Access Policy Articles, as set forth at http:// nrs.harvard.edu/urn-3:HUL.InstRepos:dash.current.terms-of-use\#OAP

\section{Share Your Story}

The Harvard community has made this article openly available.

Please share how this access benefits you. Submit a story.

Accessibility 


\section{Deliberate about, not in, Elections}

Dennis F. Thompson

9-6-13

Prepared for Election Law Journal, vol. 12(4) (November 2013)

What can election law contribute to deliberative democracy? Election law can try to make elections more deliberative; or it can try to make deliberation more electoral. It can focus on deliberation in elections or deliberation about elections. These approaches are not of course mutually exclusive. But the first, which is more common, is problematic, and the second, less appreciated, is more promising. Which approach we emphasize affects how we assess judicial decisions and proposals for reform, as well as legal doctrines about the electoral process.

\section{Deliberative Democracy}

What would it mean to make elections more deliberative? Deliberative democracy comes in many flavors, and has something to offer almost every election lawyer. ${ }^{1}$ That is part of its appeal but also part of the difficulty in identifying its distinctive requirements. In some forms, it seems to be simply a demand that citizens meet together to discuss politics so that they can become better informed about the candidates and issues of the day. It may also call on candidates for office to debate one another so that voters will know better where they stand, and can choose the party or candidate more in line with their own views.

Most deliberative democrats agree that these are worthy aims, but so would most other kinds of democrats. The ideas that voters should talk about issues and candidates to become better informed and that campaign discussion should help them make more informed choices are not exclusive to deliberative democracy. They are no less central to conceptions that are often contrasted with deliberative theories, such as competitive theories, the most prominent alternative in the election law literature. ${ }^{2}$ Part of the point of making elections competitive is to give voters clear and meaningful choices among candidates and parties. Competitive theorists would favor any practices (including political discussion) that help voters to become better informed about the choices they have to make. Nor do competitive theorists rule out any particular method of informing voters. Presenting reasons for one's opinions may not always be the most effective way of persuading voters, but it is a standard part of the repertoire of candidates in a competitive campaign. 
To sharpen the contrast between deliberative and other conceptions of democracy, we should focus on requirements of deliberative democracy that are not typically found in other conceptions, at least not to the same degree or with the same salience. ${ }^{3}$ Three are most relevant.

The first is that that the reason-giving process should be reciprocal. ${ }^{4}$ Participants give reasons that should be acceptable to anyone trying to find reasonable terms of cooperation in circumstances of political disagreement. The reasons may refer to particular interests, but they should also show how the proposal in question serves a wider public. They should amount to more than strategic communication intended to serve only the interests of a single group or party. Participants should try to find a basis for agreement that could improve on the status quo for all citizens, and - equally important - to maintain mutual respect when, as is usual in politics, disagreement persists. ${ }^{5}$

The second requirement is that the process should encourage what has been called provisionality. ${ }^{6}$ That implies simply that participants should be open to changing their opinions in reaction to the reasons their opponents offer. The change should come in response not only to new facts or changed circumstances (as most theorists would recognize) but also to arguments about basic values (as they apply to policies, candidates and parties). Preferences are not to be regarded as fixed but rather as subject to revision in the give-and-take of the political process. In some cases the deliberators may be convinced by opponents' arguments, but even when they are not, they may decide that on balance it is reasonable to accept a compromise.

Finally, the process should include as diverse a set of perspectives as possible consistent with productive discussion. ${ }^{7}$ Diversity of perspectives is assumed to improve the quality of the deliberation and the decisions that it produces. The requirement differs from the general egalitarian requirement found in most democratic theories. Although deliberative democrats also believe that all citizens should have an equal right to participate in governing or at least in choosing their representatives, the distinctive requirement of diverse deliberation is both more and less demanding. It is more demanding because it calls for affirmative efforts to bring neglected perspectives into the deliberation, regardless of the number or intensity of their representation in the electorate. It is less demanding because it may be satisfied if the perspectives are represented in the deliberation, regardless of whether every citizen has a chance to participate.

\section{$\underline{\text { Deliberative Elections }}$}


Elections are not an obvious place to seek more deliberative democracy. Voting is the least deliberative act in the public democratic process. It appears more an act of will than of reason. Voters no doubt have their reasons for voting as they do, and analysts devote much effort to trying to discern them. But voters are not obligated to give any reasons for their decisions. They do not have to justify themselves to anyone. Individually they simply mark their ballot, and collectively they thereby express the popular will. ${ }^{8}$

If voting itself remains opaque to deliberative scrutiny, the steps leading up to the act offer more possibilities for deliberative improvement. The campaign is the place in the electoral process that most obviously might seem to benefit from more deliberation. Certainly many deliberative theorists think so. ${ }^{9}$ Some have devoted considerable ingenuity to devising devices that would help realize this objective. The cause has attracted not only deliberative theorists but also political leaders and even supreme court justices who are not usually regarded as deliberative democrats. Consider this declaration by Justice Kennedy: "Deliberation on the positions and qualifications of candidates is integral to our system of government" ${ }^{\text {"10 }}$

However, making elections deliberative is problematic, first, because it would undermine the essential character of campaigns, and frustrate one of its key purposes. Campaigns function best as strategic interactions with zero-sum outcomes, not as deliberative exchanges with joint gains. They are winner-take-all contests, not win-win negotiations. If candidates were to try to seek agreement with their opponents, as the deliberative requirement of reciprocity suggests, they would serve less well not only their own cause but also the democratic value of the campaign. They would deprive voters of a clear and distinct choice—-subverting a basic purpose of campaigns in a democracy.

To underscore why campaigns are not a time to cooperate, consider this extreme but actual example of an electoral concession. It took place in a race for a seat in the Colorado state senate in 1996 - a hotly fought contest between the Democrat Laurie Bower, and the Republican Dave Wattenberg. Four days before the election Bower announced that, after much deliberation, she had concluded that Wattenberg was "in a better position to help the people of this district." She would "put aside the partisan differences," and immediately withdraw from the race. ${ }^{11}$ Bower's action was inappropriate for many reasons, but most fundamentally because she completely disrupted the competitive process that would have given voters a choice. She turned a deliberative virtue into a strategic vice. Her attitude, suitably adjusted, might have been admirable 
in legislative negotiations where parties were trying to reach bipartisan compromises, but here it was not only disloyal to the party but also detrimental to the electoral process.

Neither should voters usually adopt a cooperative attitude in campaigns. Some citizens may wish to organize nonpartisan forums and public-spirited websites to inform all voters better, but the campaign depends on most citizens' pursuing their partisan goals, organizing and mobilizing their like-minded compatriots. If they were to spend too much time talking to opponents, they would become less zealous, more tolerant, and (as some studies show) less likely to be politically active. ${ }^{12}$ (The tendency to associate exclusively with like-minded fellow citizens may be undesirable in a deliberative democracy, but in campaigns it is often functional.)

The deliberative requirement of provisionality also undermines the aim of producing a clear choice for voters. Candidates who keep an open mind, and seem willing to change in response to the criticisms of opponents, are not only less likely to win, but they are also more risky choices for voters. Candidates' support and ultimately their success depend on consistently affirming their commitment to partisan goals, and on distinguishing their positions sharply from those of their opponents. ${ }^{13}$ Voters need to see the differences between the candidates as clearly as possible. $^{14}$

Having a reputation for sticking to positions may be even more useful than the content of the positions themselves. As mobilization of the base has become increasingly important, candidates who want to motivate supporters have to show that they are steadfast. The overriding aim is to mobilize supporters, not to persuade opponents. ${ }^{15}$ Candidates may need to be more open to change when they govern, but if they equivocate in the campaign, they may deny themselves and their supporters the opportunity to govern.

Neither are voters open to change as the deliberative ideal might suggest. Although political scientists no longer insist that campaigns have only "minimal effects" (as the conventional wisdom in the field long held), they continue to find that campaigns largely reinforce attitudes that most voters had before the campaign started. ${ }^{16}$ Most voters cast their vote on the basis of "fundamentals"- the performance of the economy, partisan identification, and ideological compatibility. ${ }^{17}$ They do not change their views about the fundamentals during a campaign. Even most of the undecided and independent voters eventually follow their precampaign partisan inclinations. There is not much mutual mind changing here. 
But the deliberative democrat might well say: we should not accept this state of affairs, but try to reform it. Certainly the quality of campaigns can be improved. More and better information would be desirable. Rules and even laws discouraging false and misleading speech might be worthwhile and constitutionally feasible. ${ }^{18}$ Such reforms would help bring voters' choices more reliably into line with their pre-existing beliefs about the fundamentals, and help mobilize groups to go to the polls - all goals that a healthy campaign can usefully perform, and deliberative democrats readily endorse. Notice, however, that these reforms are not distinctively deliberative; they do not imply any change of mind about fundamentals, or any revisions in response to the arguments of opponents. They involve just becoming better informed about how one's pre-campaign opinions and preferences line up with the candidates and parties among which one has to choose. That is a consequence of reform that most democrats, including competitive theorists, would support. ${ }^{19}$

The second general problem with trying to make elections deliberative comes from the effect not on campaigns but on deliberation. Attempting to promote deliberation in campaigns discredits deliberation itself. In campaigns, candidates and their supporters give reasons for their positions, but they use the reasons not primarily to reach agreement or encourage mutual respect, as deliberative democracy prescribes, but usually to gain advantage over opponents and to motivate their partisans, as campaign strategy requires.

The typical interaction is hardly an exemplar of open-minded discussion among political opponents. During the campaign citizens spend most of their time talking to people who agree with them. The efforts to persuade partisans on the other side are rare, and when they do occur are rarely successful in the heat of a campaign. Citizens might learn more about which candidates fit their pre-existing preferences, but (as already noted) few change their minds in response to discussions with people they disagree with. Except for debates, the candidates too spend most of their time with their own supporters or at least with citizens who are most likely to vote for them. "Targeting" is the "foundation of virtually every aspect of campaign strategy.", Unlike a legislator who might try to reach across the aisle to recruit cosponsors for a bill by inviting amendments, candidates do not benefit from trying to persuade the opposition by making concessions, even less by changing their own minds.

Reason-giving in the circumstances of a campaign provides a poor model for deliberation. If citizens get the idea that this is the kind of debate and communication that 
democracy promotes, they are less likely to develop the skills and inclinations they need for the more reflective and substantive discussion that the deliberative ideal seeks. They may also be more likely to take a cynical attitude toward the rare moments of genuine deliberation that happen to occur in the campaign. Candidates who might otherwise favor improving the quality of campaign discourse come to see deliberative reforms as either futile (because they make such a small difference in the noise of the campaign), or perilous (because they weaken the competitive edge of the candidates who accept them).

Proponents of deliberative reforms are of course aware of the deliberative defects of campaigns. They would agree that campaign discourse as we now know it falls far short of ideal deliberation. But they would argue that if we institute some reforms, to the extent that they are successful, we will begin to provide better examples of deliberation. These efforts do not have to degrade deliberation.

But there are problems with this response. One is that it is difficult to make headway with a deliberative agenda in conditions where the incentives overwhelmingly favor adversarial competition. To the extent that the reforms are successful, the support for deliberation is likely to be fitful, and the results fragmentary, offering fleeting successes rather than stable improvements. Deliberation Day, after all, requires deliberation for only a day.

Deliberation that can make a difference requires a sustained commitment—practices and institutions that engage citizens and politicians over time in settings in which civil dialogue can take place. Campaigns are one of the least favorable environments for trying to foster this kind of discussion, and one of the most favorable for producing fodder for the critics of deliberative democracy.

Even if deliberative reforms were successful, the results would not necessarily help the reputation of deliberation as much as its proponents might hope. Campaigns are a necessary and desirable part of democracy as long as elections are the main way we choose our leaders. To the extent that deliberation weakens the competitive nature of campaigns, it may well deserve the censure of its critics. Deliberative democrats should want to protect campaigns from deliberation, and deliberation from campaigns.

To be sure, it is not easy to encourage deliberation in the other parts of the democratic process - in civil society or in government — where it is necessary and desirable. Indeed, the rise of the permanent campaign makes the task even harder, as the habits of campaigning spread into 
the practices of governing. ${ }^{21}$ It is also true that political interest is probably higher during a campaign than at other times. But the difficulty of promoting deliberation where it is appropriate is not a reason to try to promote it where it is not.

\section{Regulating Campaigns}

If these doubts about deliberative campaigns are well founded, then we should be more cautious about expanding the scope of deliberation. For the purposes of election law, we should adopt an approach to deliberative democracy that focuses less on deliberation in campaigns and more on deliberation about elections. Deliberative democracy is capable of self-restraint; it does not require deliberation in all parts of the political process or all the time in any part. ${ }^{22}$ With respect to campaigns, it should favor restraint for the reasons just canvassed. What are the implications of such restraint for election law?

The most general implication concerns the rationale for the legal regulation of campaigns. A restrained approach strengthens the legal doctrine of electoral exceptionalism - the view that the electoral process may be subject to more stringent regulation than ordinary politics. $^{23}$ It does so, first, by removing a standard reason for protecting campaigns from regulation. If campaigns are not important sites of deliberation, there is less reason for protecting the deliberation from regulation. To some extent, courts have already recognized that in the context of elections other values sometimes trump free speech. Consistently with exceptionalism, the courts have accepted many regulations in the electoral realm that would be intolerable in the wider domain of public discourse. They have accepted limits on what voters are permitted to express at the ballot box, requirements to disclose the identity of political speakers, and contentbased regulations of electoral speech, such as constraints on electioneering near polling places. ${ }^{24}$

However, the Supreme Court has not followed the doctrine in campaign finance cases. The majority seems to consider campaigns exceptional—but in a different sense with the opposite implication. In Citizens United, Justice Kennedy appealed to the exceptional importance of public dialogue as part of the electoral process, but in order to strike down legislative restrictions on campaign spending. If corporate-sponsored campaign ads can be prohibited, "speech would be suppressed in the realm where its necessity is most evident: in the public dialogue preceding a real election." ${ }^{25}$ A restrained deliberative democracy would join with electoral exceptionalism to push back against this tendency toward overprotection. 
Electoral exceptionalism holds only that campaigns may be subject to greater regulation. It does not necessarily say what the regulation should be. It does not by itself rule out regulation to make campaigns more deliberative. That is where the second and most important general implication of a restrained approach comes in. Such an approach shifts the agenda for reform of election law. It suggests that regulation should focus less on improving the deliberative quality of campaigns and more on removing the obstacles to voting and the counting of votes. It would give higher priority to eliminating unreasonable voter ID laws, cumbersome registration procedures, excessive limits on early voting, voter intimidation, inefficient or biased election administration, and questionable recount procedures. ${ }^{26}$

The shift would expose some differences between the competitive and deliberative conception. Deliberativists might come to conclusions that competitivists would resist. They might, for example, accept practices that advantage incumbents, even at the cost of less competition, in order to make the legislative process more deliberative. But with regard to campaigns, the shift would bring deliberativists closer to competitivists. Both deliberativists and competitivists could argue that the Court should have invalidated anti-fusion statutes, permitted open primaries at least if adopted by voter initiatives, protected ballot access more effectively, and challenged partisan gerrymandering. ${ }^{27}$ Deliberativists might even be persuaded by the competitivist argument that the so-called millionaire's amendment should be disallowed because it has the effect of protecting incumbents too much and competition too little. ${ }^{28}$

The alliance of deliberative and competitive theory could also support legislative efforts to level the playing field. Both theories could agree to favor reforms based on a principle of equality, a rationale that the Court has so far consistently rejected. They both would be more tolerant of the analogy between campaigns and games than any of the justices seem to be. In the 2011 decision that disallowed Arizona's public financing system, both the majority and dissenting opinions summarily dismissed the idea that a campaign could be similar to a competitive contest. Chief Justice Roberts wrote: “ 'Leveling the playing field' can sound like a good thing. But in a democracy, campaigning for office is not a game. It is a critically important form of speech." 29 Justice Kagan concluded her dissent with this ironic jab: "Truly, democracy is not a game."30

To be sure, campaigns are serious endeavors. They are not mere pastimes, and their stakes are not petty. But refusing to acknowledge their game-like character and continuing to 
exalt their debate-like potential reinforces the tendency to protect campaign activity from rules that may be necessary to prevent unfair practices. The protective tendency is evident in the judicial rhetoric. The opinions of both the majority and the dissenters in the Arizona case are shot through with appeals to the great importance of political discussion. There should be "robust, forceful, and contested debate" ${ }^{, 1}$ — free of any burden on the speech of candidates presumably so that open-minded voters can make up their minds by engaging with as many different views as possible. If the value of campaigns is regarded as deliberative in this sense, then the fear that regulations may be burdensome is understandable. (It is also understandable given the current state of first amendment jurisprudence.) But from the broader perspective of democratic theory, the focus should be not the burden on the candidates but the effect on the process as a whole. In a case like this the question should be not whether a system of matching funds unduly burdens the speech of candidates who do not take public financing, but whether the system serves all the goals of the democratic process including the prevention of corruption, the promotion of competition, and the reduction of distortion in political information.

Unlike these judicial opinions, and unlike an expansive deliberative theory, the restrained approach would not reject campaign finance reforms on the grounds that they discourage robust public dialogue or reduce the diversity of voices in the campaign. It could reject reforms that impaired campaign communication in other ways - for example, by distorting information voters need to bring their votes into line with their pre-campaign views. But protecting dialogue and diversity for the sake of making the campaign more deliberative would not be sufficient. Maximizing the speech of corporations and unions may bring more views into the forum and create a more robust debate, but it does not necessarily make the competition fairer, and may well distort the flow of information voters need.

In the most sustained and careful argument against deliberative campaigns by a legal scholar, James Gardner in effect provides substantial support for the approach developed here. ${ }^{32}$ He maintains that the ideal campaign should simply help voters cast their ballot consistent with the beliefs they had before the campaign. Surveying a wide range of empirical evidence, he concludes that "voters are not persuaded during a campaign to embrace, or even in most cases to contemplate, ideas that are unfamiliar or that challenge their existing beliefs." ${ }^{\text {33 }}$ Instead of a forum for debate and persuasion, a campaign is and should be only preparation for the "tabulation" ("counting heads") that constitutes the election. ${ }^{34}$ 
Gardner's case against campaign persuasion is almost persuasive. But he carries his deflationary account of campaigns too far. At one point, he suggests that campaign finance reform to make resources fairer is not important because almost no persuasion takes place during campaigns anyhow. Mobilization is what matters, and that does not require as much money as do advertising and other forms of persuasion. He writes that “...if campaigns [are understood] as tabulative, inequality of campaign resources looks much more benign., ${ }^{, 35}$

More fundamentally, Gardner seems to deny any role for persuasion at all, even some forms that both competitive and deliberative theorists would wish to preserve. ${ }^{36}$ (He does allow that some voters may be need to be persuaded to correct factual errors, and perhaps to recognize that certain issues are important than they previously believed, but he insists that "number of voters susceptible to this kind of persuasion, much less actually persuaded by campaign speech on these grounds, is likely to be small. ${ }^{, 37}$ ) To help citizens bring their votes into line with their pre-campaign views (a task for campaigns that Gardner himself endorses), campaign speech may have to be more substantively persuasive than he seems to allow. To make sure the party faithful turn out to vote, a Republican candidate may have to convince his base that the party has not abandoned the goal of fiscal conservatism despite the deficit-increasing record of the previous Republican administration. A Democratic candidate may need to reassure her base that the compromises the party leaders made in rejecting single payer health care plans were necessary to make any progress at all.

Substantive debates between candidates (even moments of deliberation) may be useful instruments of persuasion - not to persuade voters to change their minds about issues, but to adjust their opinions about the candidates' competence and character. Without themselves following the substance of the discussion in depth, voters can tell whether the candidates are taking the issues seriously, speaking candidly, taking responsibility for their past statements, and displaying other qualities that bear on political competence and constitutional character. ${ }^{38}$ Even voters who do not take the issues seriously may still insist that their nominee does.

Persuasion may take place in debates but more on the part of candidates than voters. In the course of a series of debates, candidates refine their positions, find more broadly acceptable policies, and improve their ability to justify their positions to diverse audiences. ${ }^{39}$ They modify their positions as they learn how to respond more effectively to the arguments of voters, both supporters and opponents. In debates, there is in effect a division of deliberation. Citizens 
observe so that they can learn more about the character of the candidates, but candidates deliberate so that they can learn more about the substance of the issues. This gives persuasion and deliberation a greater role than Gardner seems willing to allow. But it is still a relatively modest form of deliberation because only candidates engage in it, and only in special circumstances for limited purposes. It is still a restrained rather than a full blown deliberative democracy.

If we think of campaigns more like strategic contests than deliberative opportunities, we will tone down the high-minded rhetoric that portrays campaign speech as the cardinal contribution to a great public dialogue, and that consequently encourages resistance to all restrictions on its expression. We will respect campaigns for what they are-useful devices for helping voters select their leaders on the basis of opinions they form before the campaign. We will promote deliberation in the many other sites where political discussion and civic education should occur in a healthy democracy. The habits of genuine deliberation can be cultivated only over time in the institutions of civil society and local government. These institutions provide greater opportunities for sustained interaction. ${ }^{40}$

A restrained deliberative role for campaigns is perhaps less inspiring but it is no less significant for the democratic process. Recognizing that significance can help shift the priorities of legal and political reform. It should encourage us to put more of our resources for reform, limited as they inevitably are in politics, into changing the law and practice of campaigns so as to make competition fairer and communication less distorted. But the most important result of the shift would be to direct attention beyond the campaign to deliberation about electoral laws.

\section{$\underline{\text { Electoral Deliberation }}$}

Giving more attention to deliberation about elections implies that we should create and strengthen institutions in which citizens and their representatives deliberate about the legal structure of the electoral process - the rules governing ballot access, redistricting, voting systems, primaries, and initiatives. Many of the familiar questions of election law that are now decided by courts and legislatures would be at least in part turned over to institutions more congenial to public deliberation. We would try to design these institutions so that they would fulfill the requirements of deliberation better than the courts and legislatures, which are in any case not well suited to deal with governing electoral law. Courts tend to frame issues in terms of individual rights rather than structural goods, and legislatures tend to favor the current systems that elected their members. ${ }^{41}$ 
Because of the deficiencies of courts and legislatures, two other institutions have come to look more promising as instruments of electoral reform: independent commissions and citizens' assemblies. $^{42}$

Prima facie, these bodies have an advantage just because they are smaller. They enable a more efficient allocation of deliberation, which (deliberative democrats too often forget) is a costly practice in terms of time, attention and money. Because the number of participants is fewer, it is possible to lengthen the time and thereby enhance the quality of the deliberation. They are more efficient also because changing the electoral process affects a wider range of political decisions for a longer period of time than do the outcomes of one election or the adoption of one set of policies at a particular time.

These smaller deliberative bodies have their own disadvantages, and their achievements have so far been mixed. The purpose here is not to offer a general assessment of their performance. ${ }^{43}$ If we can assume that an institution like a citizens' assembly can be designed to meet deliberative requirements, we can ask what it should deliberate about. Focusing on reforming electoral law is more promising than trying to make campaigns more deliberative.

The first reason that electoral deliberation is more promising is that its purpose is to improve a process - the electoral system - in ways that in principle can benefit all citizens and candidates. The aim is not the victory of one party or one candidate but the enhancement of the democratic process. The outcome does not have to be zero-sum and the interactions do not have to be strategic. ${ }^{44}$ The deliberation take place in a public forum in which the participants offer reasons that can be accepted by their opponents, and seek results that could benefit all parties. This reciprocity is quite different from a campaign where the main point is to defeat your opponent. Also in electoral reform, the consequences of changes are not as direct. Any advantages of apparent victory seem distant and, in the case of citizens assemblies or independent commissions, do not affect the deliberators directly.

The deliberation does not of course take place behind a veil of ignorance. Participants can foresee the partisan effects of some of the reforms, and many will no doubt favor changes that would advantage their own groups or parties. Citizens who identify with smaller groups and insular minorities, for example, are likely to favor proportional rather than majoritarian systems. Deliberation will still be political, but it need not be parochial. When civic minded citizens are 
recruited and assembled in the right way, and incumbent politicians and potential candidates are excluded, the process can be genuinely deliberative.

A second reason to focus on electoral deliberation is that the process is more conducive to provisionality. Participants come to the process with fewer fixed beliefs and less intense opinions. They are consequently more open to accepting new ideas and changing their minds in the course of discussion than they would be in a campaign. This openness is partly due to the subject of deliberation: most people (except perhaps election lawyers and some political theorists) do not have passionate views about the relative merits of various PR systems, open v. closed primaries, or standards for redistricting. It is also partly due to the setting: there are more opportunities for low-keyed discussions in smaller groups that meet for several months than in the short-term encounters that typically occur in the heat of a campaign. Perhaps most importantly, participants have to engage in a serious way with a wider range of perspectives than during political campaigns. Although they may not agree with their fellow participants, they have to listen and respond to their arguments. As a result, they are more likely to find points of agreement, or at least to accept the differences that remain.

Finally, electoral deliberation, at least in institutions like the citizens' assembly, can come closer to satisfying the diversity requirement — the demand to bring different perspectives into the discussion. That diversity will not come about spontaneously; random selection does not guarantee it either. The criteria for inclusion and the procedures of recruitment need to be systematically designed to produce a body that represents a wide range of views. That is often not easy. But it more feasible than trying to make deliberative bodies representative during a campaign when partisan diversity is likely to be the most salient criterion, and partisan commitment the strongest incentive for participation. Furthermore, if some perspectives are not initially represented, the chances of their being expressed by others (and seen as being expressed) are greater in a deliberative body that meets over a long period in a time of less intense political activity.

Deliberative democracy favors deliberation about the electoral process but it does not dictate deliberative solutions to the problems of electoral law. This important distinctionbetween the process and outcome of electoral deliberation - is obscured when, as often happens, the requirements of deliberative theory are directly applied to evaluate proposals for changes in election law. Such an approach is prevalent because it seems a natural way of connecting 
electoral practice with normative theory. But it makes deliberative theory appear more rigid than it is, and misses one of its major advantages.

In one of the more systematic attempts to use normative criteria to assess the electoral process, Keena Lipsitz argues that deliberativists should favor Proportional Representation (PR), while competitivists may be indifferent between PR and First-Past-the-Post (FPTP), and both should favor systems that permit fusion candidacies. ${ }^{45}$ However, the connections are not as tight as she suggests. Deliberativists could prefer FPTP because it tends to produce two-party systems, which under some conditions encourage more interaction among citizens with diverse views, than do multi-party systems, in which the negotiations are left to legislators. Similarly, deliberativists' conclusions about third parties (which are helped by fusion systems) are also more conditional than she and others suggest. ${ }^{46}$ Debates and other forums for discussion (such as Deliberation Day) can be more focused and coherent if they involve only two parties. More generally, the particular procedures and reforms that deliberative democracy should favor are significantly contingent; their relative merits depend substantially on particular circumstances and the likely tendencies of the political system in question. Deliberative democracy is in that respect no different from any plausible normative theory that might be usefully applied to assess the electoral process.

Deliberative democracy has a further advantage — one that is obscured by the direct application of its requirements. The advantage can be seen more clearly by recognizing that it functions more as a second- rather than a first-order theory. A first-order theory seeks to resolve moral disagreement by rejecting alternative theories and principles. Its aim is to be the single theory that resolves moral disagreement. The most familiar conceptions of justice-utilitarianism, libertarianism, liberal egalitarianism, communitarianism - are first-order theories in this sense. Each claims to resolve moral conflict in ways that require rejecting the principles of its rivals. A second-order theory adjudicates among first-order theories by providing ways of dealing with their conflicting claims. It makes room for continuing moral conflict that first-order theories claim to eliminate. It can be held consistently without rejecting a wide range of principles expressed by first-order theories.

Thus, in the process that deliberative democracy recommends, participants are able to consider many different values, as well as various contingencies. They can balance the value of deliberation against the value of competitiveness when they conflict. They could decide in favor of a legal reform that promotes competition at the expense of deliberation. They might even 
decide to adopt reforms that would make campaigns somewhat more deliberative. That is why the two approaches (deliberative elections and electoral deliberation) are not mutually exclusive. But of course electoral deliberators could not go very far in making campaigns deliberative without running into the problems discussed earlier.

In electoral deliberation, then, deliberative democracy does not require that the participants choose only deliberative reforms, but it does insist that the decision making process conform to the principles of deliberative democracy. These include the three requirements set out above, but they also imply other norms of deliberation. ${ }^{47}$ One important norm is that deliberators should give justifications not only when change is proposed, but also when it is resisted. This is especially relevant to discussions about election law. Like much of the rest of the democratic process, the electoral system is a set of politically constructed institutions, defined by rules that citizens and their representatives could alter. There is no default position, no electoral state of nature that must be presumed to prevail in the absence of compelling reasons to abandon it. Declining to regulate campaign finance is no less a choice, no less in need of justification, than deciding to regulate it.

Electoral deliberation is not only a theoretical aim but also a practical possibility. Commissions for election administration and reform, have proliferated in democracies throughout the world, and some are recognizably deliberative in aim. ${ }^{48}$ The potential for electoral deliberation can be seen most dramatically in the Citizens' Assembly established in British Columbia in $2004 .^{49}$ The Assembly was composed of 160 (more or less randomly chosen) ordinary citizens, who were asked to deliberate about whether to change the province's electoral system and if so how to modify it. This was the first time in the history of democracy that a body of ordinary citizens had been authorized to recommend a major change in the electoral system of a state. Since then, this institutional innovation has been adopted by other Canadian provinces and also in the Netherlands.

The BC Citizens' Assembly was charged with deciding whether to keep the province's FPTP system, or replace it with some form of proportional representation. The group spent nine months - mostly long weekends - learning and arguing about electoral systems. They concluded that the current system should be changed, and that the two best alternatives were a mixed member system (similar to Germany's) and proportional representation (similar to Ireland's). In the end they opted for proportional representation, specifically a system of the single transferable 
vote. Their proposal did not win the required super majority when submitted to the electorate in two separate referendums.

Despite the outcome of the referendums, deliberative democrats should be encouraged by the quality of the discussion in the Assembly. ${ }^{50}$ Nearly everyone who observed and studied the assembly was impressed by how well informed and public spirited the members became during this process. Generally, the tenor was deliberative in ways that should warm the hearts of not only deliberative democrats but any democrat who wishes to give citizens greater control of the electoral process. The members did not come across as partisans or zealous advocates. They acknowledged the virtues of the other systems, appreciated the arguments of their opponents, and sometimes changed their minds. ${ }^{51}$

The Assembly came about as a result of political events and principled leadership that cannot be counted on to occur regularly. And it required an investment of time and money that cannot be expected to be allocated routinely. Moreover, the process was not without flaws: the members did not have complete control over the agenda, some participated more than others, and some groups were not adequately represented.

The most serious problem with this kind of electoral deliberation is not the difficulty of establishing an effective assembly, but the challenge of reducing the inevitable gap between any such assembly and the general public. The members of these institutions engage in a process of deliberation that the electorate can never hope to match. Members enjoy an opportunity that their fellow citizens cannot share. They are changed by the experience in ways that sets them apart from the electorate. They reach conclusions for reasons that most ordinary voters are not likely to fully appreciate. Designed to reduce the gap between citizens and experts, the process itself reproduces the problem that it was intended to overcome.

It should be possible at least to reduce this gap. If assembly members take seriously their obligation to explain the process to voters, and voters are prepared to trust the judgment of members, the moral gap disappears, even if a competence gap remains. A voter can say to an assembly member not only, "I trust you because you engaged in a process that seems fair and reasonable" (that might be said to any representative), but also "I trust you because you are a person not so different from me, and you decided as I can imagine that I might have done in similar circumstances." There is some evidence that the B.C. voters thought in exactly these terms as they decided how to vote in the first referendum-when the Assembly's proposal won 
substantial majorities. ${ }^{52}$ Had more thought in these terms, the proposal may well have carried. Unlike members of expert commissions, some legislators and other elites, assembly members not only are ordinary citizens before they serve but also resume that role after they serve. Their service exemplifies a pure form of rotation in office: Ruling and being ruled in turn-thus recapturing the classical idea of democracy.

But even if the citizens who vote trust the assembly, a related problem remains. Except for the first referendum in $\mathrm{BC}$, the turnout in the votes on the proposals from these assemblies has been disappointing. Even if the proposals had won approval, their legitimacy would have been in doubt. Deliberative democrats, like all good democrats, should not want to impose the basic electoral system on an electorate that has not shown more support than has been seen so far. In the Canadian referendums, most knew little about the assemblies, and "many were misinformed about their nature and composition." ${ }^{, 53}$ One of the major causes of the low turnout and low levels of interest was the relative lack of vigorous participation by the political parties and other activist organizations. ${ }^{54}$ Partly as a consequence, the media did not cover the referendums as extensively as they would have in a political campaign. It is not surprising that fewer citizens took the trouble to vote.

The implication of this problem is ironic. We set aside the project of deliberative campaigns only to find we apparently now need campaigns to finish the project of electoral deliberation. We seem to need deliberation in elections in order to legitimize deliberation about elections. To justify the changes in election law that electoral deliberation produces, we may have to resort to a process that looks more like the political campaigns that discourage deliberation.

The problem of the gap between the deliberative bodies and the general public is real but addressing it does not require relying on political campaigns of exactly the kind that precede ordinary elections. The question in the referendums, after all, is not which party or candidate should win, but whether a change in the system by which voters choose among parties and candidates will benefit all citizens in the future. Because it is not partisan and zero sum like an ordinary election, it does not necessarily generate the narrowly strategic appeals and pervasive mutual mistrust that characterize ordinary campaigns. Its purpose is not undermined by deliberation.

Notice also that the case against the deliberative campaign does not apply directly if at all to referendums and especially initiatives. Unlike ordinary elections they do not choose leaders to 
govern, they enable the people themselves to govern. That means that it makes less sense to limit deliberation to governing in office. If there is to be any deliberation at all, it must take place in the campaign. ${ }^{55}$ On the particular issue on the ballot, the initiative campaign is the last clear chance for deliberation.

But a challenge remains: how to stimulate greater interest and foster more participation in a decision about a complex, impersonal question of the kind that direct elections pose? It would probably help if the campaign were not about so much about the merits of the particular reforms and more about the body recommending them. The debate would be more personal and accessible if it focused on who the members were, how they conducted themselves, the fairness of the proceedings, and other features of the assembly itself. That would make the campaign discourse more accessible, and probably more interesting to more voters. In designing the campaigns, we could also learn from the best practices of initiative campaigns that were successful in generating informed participation (and from the deficiencies of those that were not). ${ }^{56}$

Also, we should resist the practice of setting higher thresholds for approval of electoral initiatives than for other kinds. Although the practice is not without justification (constitutional changes typically require supermajority approval), it biases the system in favor of the status quo. In the case of the electoral process, the status quo consists of laws and procedures that have not been approved by supermajorities in the first place, some of which are the result of reforms mostly instituted by elites. ${ }^{57}$

If we can find ways to encourage more interest and participation in electoral reform, we will not only strengthen the legitimacy of election laws, but also contribute to public understanding of this essential part of the democratic process. That would be a greater benefit in the long run than increasing what citizens learn about policies and candidates in a particular election. What kind of election laws citizens choose directly or indirectly affects all the other political choices they ultimately make. That is a fundamental reason why electoral deliberation should have a higher priority than deliberative elections in the law of deliberative democracy. 


\section{NOTES}

1. For an overview of the varieties, see Amy Gutmann and Dennis Thompson, Why Deliberative Democracy? (Princeton NJ: Princeton University Press, 2004), 21-39.

2. Richard Posner draws the sharpest contrast [ (Law, Pragmatism, and Democracy (Cambridge: Harvard University Press, 2003)], 130-57. Richard Pildes shows that the contrast is exaggerated ["Competitive, Deliberative, and Rights-Oriented Democracy," Election Law Journal 3, no. 4 (2004): 685-697. The seminal statement of competitive theory in the election law literature is: Samuel Issacharoff and Richard H. Pildes, "Politics as Markets: Partisan Lockups of the Democratic Process," Stanford Law Review 50 (1998): 643-717. In political theory, competitive theorists extend the views of Joseph Schumpeter, Capitalism, Socialism and Democracy (London: George Allen and Unwin, 1961): see Ian Shapiro, The State of Democratic Theory (Princeton: Princeton University Press, 2003), 58-62, 108-09. For a critique, see Gerry Mackie, "Schumpeter's Leadership Democracy," Political Theory 37, no. 1 (2009): 128-153. For a partial defense, see Jeffrey Edward Green, “Three Theses on Schumpeter: Response to Mackie," Political Theory 38, no. 2 (2010): 268-275.

3. The purpose of identifying the distinctive characteristics is not to try to deny the honor (or the stigma) of "deliberative democracy" to other kinds of political discussion, which are often, and unobjectionably, called deliberation. Rather, it is to recognize that some of the normative and empirical consequences of deliberation as defined here differ from the consequences of other kinds of political deliberation and discussion. More generally, on these differences and on the significance of the conceptual criteria in analyzing deliberative democracy, see Dennis F. Thompson, "Deliberative Democratic Theory and Empirical Political Science," Annual Review of Political Science 11 (2008): 501-05.

4. Amy Gutmann and Dennis Thompson, Democracy and Disagreement (Cambridge, Mass.: Harvard University Press, 1996), 128-64; and Why Deliberative Democracy? 3-4. Also see Joshua Cohen, "Procedure and Substance in Deliberative Democracy," in S. Benhabib, ed., Democracy and Difference (Princeton University Press, 1996), 95-119; and "Deliberation and Democratic Legitimacy,” in David Estlund, ed., Democracy (Oxford England: Blackwell Publishers, 2002), 87-106.

5. Participants can demonstrate mutual respect in various ways-for example, by avoiding negative attacks that impugn the motives of opponents and manipulative rhetoric that misleads 
their potential supporters. See the discussion of the "economizing on disagreement" in Gutmann and Thompson, The Spirit of Compromise (Princeton: Princeton University Press, 2012), 117-29.

6. Gutmann and Thompson, Why Deliberative Democracy? 6-7, 57-59, 110-19.

7. James Bohman, "Deliberative Democracy and the Epistemic Benefits of Diversity," Episteme (2006) 3, no. 3, 175-90; and David M. Estlund, Democratic Authority: A Philosophical Framework (Princeton: Princeton University Press, 2009), 185 219, 232.

8. Some theorists initially opposed the secret ballot because it seemed to express the idea that voting is a private matter instead of a public trust, and implied that voters do not owe anyone a justification for how they vote. On John Stuart Mill's opposition to the secret ballot, see Dennis F. Thompson, John Stuart Mill and Representative Government (Princeton: Princeton University Press, 1976), 98-99. For a contemporary argument sympathetic to public voting, see Geoffrey Brennan and Philip Pettit, "Unveiling the Vote," British Journal of Political Science 20 (July 1990): 311-34.

9. Bruce Ackerman and James S. Fishkin, Deliberation Day (New Haven: Yale University Press, 2005); Fishkin, The Voice of the People: Public Opinion and Democracy (New Haven: Yale University Press, 2005); John Gastil and Peter Levine, The Deliberative Democracy Handbook (San Francisco: Jossey-Bass, 2005); Joseph Bessett, "Should Election Campaigns Be Deliberative?" Election Law Journal 9, no. 3, (2010): 197-210; and Graeme Orr, "Deliberation in Electoral Law," paper presented at the Symposium on the Law of Deliberative Democracy, Straus Institute for the Advanced Study of Law and Justice, New York University, April 5-6, 2013. Also see Keena Lipsitz, "Democratic Theory and Political Campaigns," Journal of Political Philosophy 12, no. 2 (2004): 163-189; and Competitive Elections and the American Voter (Philadelphia: University of Pennsylvania Press, 2012). Lipsitz mainly argues for more competitive campaigns but suggests that they would reinforce deliberative goals as well (26-29). One of the few deliberative democrats to explicitly repudiate the normative ideal of a deliberative campaign is $\mathrm{C}$. Edwin Baker, "Implications of Rival Visions of Electoral Campaigns," in W. Lance Bennett and Robert M. Entman, eds., Mediated Politics: Communication in the Future of Democracy (Cambridge UK: Cambridge University Press, 2001), 342-61; also see his "Campaign Expenditures and Free Speech," Harvard Civil Rights-Civil Liberties Law Review 33 (winter 1998): 1-55.

10. Arkansas Ed. Television Comm., v. Forbes, 523 U.S. 666 at 676 (1998). In Citizens United, Justice Kennedy quotes almost the same phrase again (though using "discussion" instead of 
"deliberation"): "Discussion of public issues and debate on the qualifications of candidates are integral to the operation of the system of government established by our Constitution" Citizens United v. FEC 558 U.S. 310, 898 (citing Buckley v. Valeo 424 U.S. 1 (1976). The rest of the paragraph elaborates on the idea: “...debate on public issues should be uninhibited, robust, and wide-open..." and the constitutional guarantee "has its fullest and most urgent application precisely to the conduct of campaigns for political office" (Buckley at 15, quoting various opinions). For other examples of judicial and legislative appeals to deliberative ideals, see James A. Gardner, What are Campaigns For? The Role of Persuasion in Electoral Law and Politics (New York: Oxford University Press, 2009), 45-81. Gardner argues that the rhetoric does not reflect the reality: “...federal constitutional law bows frequently and reverentially to the concept of election campaigns as forums for political persuasion, yet in its actual operation institutionalizes a system in which significant, meaningful persuasion is not realistically to be expected, and in fact may at times be powerfully suppressed" (57).

11. Kathleen Adams et al., "The Election Notebook," CNN Time, November 6, 1996, http://cgi.cnn.com/ALLPOLITICS/1996/elections/time.special/notebook.shtml.

12. Diana C. Mutz, Hearing the Other Side: Deliberative vs Participatory Democracy. Cambridge and New York: Cambridge University Press, 2006).

13. See e.g. Ronald A. Facucheux, ed., Winning Elections: Political Campaign Management, Strategy and Tactics (Lanham MD: Rowman and Littlefield, 2003), 67-68.

14. In the candidate-centered campaigns that have become more prevalent in our time, the differences that matter are to be found less in the issues than in the personalities. See Gary C. Jacobson, The Politics of Congressional Elections (New York: Longman, 2009), $7^{\text {th }}$ edition, 63; and Martin P. Wattenberg, The Rise of Candidate-Centered Politics: Presidential Elections of the 1980s (Cambridge MA: Harvard University Press, 1992).

15. Thomas M. Holbrook and Scott D. McClurg, "The Mobilization of Core Supporters: Campaigns, Turnout, and Electoral Composition in United States Presidential Elections," American Journal of Political Science 49 (2005): 689-701. Even in a system with compulsory voting and high turnout, the primary goal is not to persuade the opposition but to reinforce the base so that potential supporters actually cast their ballots for the candidates who most closely match their pre-campaign preferences. 
16. For surveys of the literature, see Gardner, What are Campaigns For? 283-113; Michael Alvarez, Information and Elections (Ann Arbor: University of Michigan Press, 1997); and Thomas M. Holbrook, Do Campaigns Matter? (Thousand Oaks, CA, 1996). Also see, Richard Johnston, Michael G. Hagen, and Kathleen Hall Jamieson, The 2000 Presidential Election and the Foundations of Party Politics (Cambridge, UK: Cambridge University Press, 2004); David M. Farrell and Rüdiger Schmitt-Beck, Do Political Campaigns Matter? (New York: Routledge, 2002); Shanto Iyengar and Adam F. Simon, "New Perspectives and Evidence on Political Communication and Campaign Effects," Annual Review of Psychology 51 (2000): 149-69; and Andrew Gelman and Gary King, "Why are American Presidential Election Polls so Variable When Votes are so Predictable?” American Political Science Review 23 (1993): 419-51.

17. See especially Johnston et al., 4, 60-64, 174-75.

18. Richard Hasen suggests that narrowly drawn laws "aimed at stopping maliciously false speech about the conduct of elections and those laws targeting defamatory false statements about candidates" would likely would survive constitutional challenge. The state also has "the power to bar false statements from official ballot materials and probably to establish a 'truth-declaring' commission to make pronouncements about campaign lies.” But in light of U.S. v. Alvarez [132 S. Ct. 2537 (2012)], it may no longer be constitutional for a state "to ban or punish malicious false campaign speech, whether made by candidates or others" [Richard L. Hasen, "A Constitutional Right to Lie in Campaigns and Elections?” Montana Law Review (2013)].

19. For an earlier effort to suggest some reforms that deliberative democrats could support even on a limited conception of the role of campaigns, see Dennis F. Thompson "Two Concepts of Corruption: Making Campaigns Safe for Democracy," George Washington Law Review 73, no. 56 (2005): 1046-54.

20. Paul S. Herrnson, Congressional Elections (Washington: Congressional Quarterly Press, 2008), $5^{\text {th }}$ edition, 205.

21. Norman J. Ornstein and Thomas E. Mann, eds., The Permanent Campaign and its Future (Washington, DC: American Enterprise Institute, 2000).

22. See the discussion of the allocation of deliberation in the "structure of deliberative democracy" in Dennis F. Thompson, "Deliberative Democratic Theory and Empirical Political Science," 51316. More generally, see Jane Mansbridge et al., "A Systemic Approach to Deliberative Democracy," in Deliberative Systems, ed. John Parkinson (Cambridge University Press, 2012), 1- 
26; and James Bohman and Chad Flanders, “Can Election Law be Deliberative?” presented at the Symposium on the Law of Deliberative Democracy, Straus Institute for the Advanced Study of Law and Justice, New York University, April 5-6, 2013.

23. See especially Richard Briffault, "Issue Advocacy: Redrawing the Elections/Politics Line," Texas Law Review 77 (June 1999) 1753-54. Other important defenses of the idea of an electoral domain distinct from ordinary politics are Frederick Schauer and Richard Pildes, "Electoral Exceptionalism and the First Amendment," Texas Law Review 77 (June 1999): 1803-36; and Baker, "Campaign Expenditures and Free Speech," 1-55. Also see Dennis F. Thompson, "Election Time: Normative Implications of Temporal Properties of the Electoral Process in the United States," 98 American Political Science Review 59-61 (February 2004).

24. Schauer and Pildes, "Electoral Exceptionalism" 1816-17.

25. Citizens United v. FEC, at 917.

26. For a sampling of the problems and some possible solutions: Richard L. Hasen, The Voting Wars: From Florida 2000 to the Next Election (New Haven: Yale University Press, 2012); Justin Levitt, "Election Deform: The Pursuit of Unwarranted Electoral Regulation,” Election Law Journal 11, no. 1 (2012): 97-116; Edward B. Foley, "How Fair Can Be Faster: The Lessons of Coleman v. Franken," Election Law Journal 10, no. 3 (2011): 187-226; and Lawrence Norden, How to Fix Long Lines (Brennan Center for Justice, New York University, 2013 http://www.brennancenter.org/sites/default/files/publications/How_to_Fix_Long_Lines.pdf

27. Issacharoff and Pildes, "Politics as Markets"; Pildes, "The Theory of Political Competition," Virginia Law Review 85, No. 8 (1999): 1605-1626; and Pildes, “Competitive, Deliberative...” 689.

28. Davis v. Federal Election Commission, 554 U.S. 724 (2008). The Court struck down the section of the Bipartisan Campaign Reform Act of 2002 that in effect allows candidates for the House, whose opponents spend more than $\$ 350,000$ of their own money, to accept triple the amount of contributions otherwise permissible under the law (subject to certain conditions).

29. Arizona Free Enterprise Club's Freedom Club PAC v. Bennett (2011) 131 S. Ct. 2806, 2826

30. Arizona Free Enterprise Club’s Freedom Club PACv. Bennett at 2846

31. Arizona Free Enterprise Club's Freedom Club PAC at 2806, 2835, 2829. 
32. Gardner, What Are Campaigns For? More recently, Gardner has offered another, different argument against using deliberative democracy to guide reform of election law: they have incompatible aims. The former aims at inclusion and challenge to majorities while the latter aims at inclusion and protection of minorities. His argument is interesting, but it makes a broader and more problematic claim than is necessary for establishing the case against deliberative campaigns. See James Gardner, "The Incompatible Treatment Of Majorities In Election Law And Deliberative Democracy," paper presented at the Symposium on the Law of Deliberative Democracy, Straus Institute for the Advanced Study of Law and Justice, New York University, April 5-6, 2013.

33. Gardner, 104. He also shows that many deliberative theorists are not as committed as they might seem to making campaigns deliberative, or at least they should not be (134-45).

34. Gardner, 182.

35. Gardner, 175. He acknowledges that unequal resources can distort the "tabulation" and might have to be regulated for that reason (176).

36. See Richard Briffault, "Election Campaigns and Democracy," Buffalo Law Review 58 (2010): $1175^{-1187 .}$

37. Gardner, 106.

38. Dennis F. Thompson, “The Primary Purpose of Presidential Primaries," Political Science Quarterly 125, no. 2 (Summer 2010): 229-31.

39. Referring to how Obama learned from his poor performance at a candidate forum and other joint appearances, David Axelrod observed that "It took a while to figure out how to swim...As bright and as gifted as he is...he went through a period that was very difficult...Little by little he began to learn the rhythm and the pace and the requirements." [Dan Balz and Haynes Johnson, The Battle for America 2008 (New York: Viking 2009), 74].

40. See Gutmann and Thompson, Democracy and Disagreement, 358-6o. For analyses of deliberation in participatory governance, see Archon Fung and Erik Olin Wright, Deepening Democracy: Institutional Innovations in Empowered Participatory Governance ( Verso Books, 
2003); and Archon Fung, Empowered Participation: Reinventing Urban Democracy (Princeton NJ: Princeton University Press, 2009).

41. Dennis F. Thompson, "Who Should Govern Who Governs? The Role of Citizens in Reforming the Electoral System," in Mark E. Warren and Hillary Pearse, eds., Designing Deliberative Democracy: The British Columbia Citizens' Assembly (Cambridge University Press, 2008), 23-25

42. There are opportunities for deliberative interactions within the regular procedures of government, such as the pre-clearance process required by Section 5 of the voting act, in which states propose electoral changes, the Justice Department responds, and the state may make further revisions. See Yasmin Dawood, "Second-Best Deliberative Democracy And Election Law," paper presented at the Symposium on the Law of Deliberative Democracy, Straus Institute for the Advanced Study of Law and Justice, New York University, April 5-6, 2013.

43. Warren and Pearse, eds., Designing Deliberative Democracy. For a more recent assessment, see Michael Pal, "The Promise and Limits of Citizens' Assemblies: Deliberation, Institutions, and the Law of Democracy," Queen's Law Journal 38, no. 1, (2012): 259-296.

44. Bruce Cain proposes a procedure for redistricting, modeled after the New Jersey commission, that in effect uses competitive means to serve deliberative ends. The parties present competing plans in an iterative fashion, responding to goals set by the citizens commission, which then can choose the best, or create a modified one of its own. [" Redistricting Commissions: A Better Political Buffer," Yale Law Journal 121 (2012): 1838-41].

45. Lipsitz, "Democratic Theory and Political Campaigns," 178-79, 185.

46. For an example of the various considerations that should go into a decision about whether to favor fusion systems, see Dennis F. Thompson, Just Elections: Creating a Fair Electoral Process in the U.S. (Chicago: University of Chicago Press, 2002), 70-80.

47. Thompson, Just Elections, 191-95.

48. Cain concludes that the "most important feature of independent citizen [redistricting] commissions in the future may turn out to be... their capacity to negotiate to meet supermajority vote thresholds and agree on reasonably imperfect plans (i.e., good redistricting deliberation)' (p. 1843) [emphasis added]. For a survey of election commissions in several different countries, and 
an agenda for future research, see Christopher S. Elmendorf, "Election Commissions and Electoral Reform: An Overview," Election Law Journal 425 (2006): 425-45.

49. Generally, see Warren and Pearse, eds., Designing Deliberative Democracy. Some parts of the discussion that follows are drawn from my contribution to that volume, "Who Governs..."

50. Thompson, "Who Governs...” 191-95.

51. In a speech on the last day that many later praised, Ray Spaxman, a member representing Vancouver, captured this spirit quite well. He said he had listened to the speeches, read the web pages, and had tried to remain open-minded, and believed that others had also done so. He had gone "back and forth" about his conclusion, and could still "waver," but was inclined to vote for STV [Thompson, "Who Governs...” 38].

52. Fred Cutler, Richard Johnston, R. Kenneth Carty, André Blais, and Patrick Fournier, "Deliberation, Information, and Trust: the British Columbia Citizens' Assembly as Agenda Setter" in Designing Deliberative Democracy, 166-91. Also see Patrick Fournier, Henk van der Kolk, R. Kenneth Carty, André Blais, Jonathan Rose, When Citizens Decide: Lessons from Citizens' Assemblies on Electoral Reform (Oxford: Oxford University Press, 2011). Ron Levy finds evidence showing that in the Australian context public trust would be substantially greater for a citizens' assembly than for traditional processes of electoral reform ["Breaking the Constitutional Deadlock: Lessons from Deliberative Experiments in Constitutional Change," Melbourne University Law Review 34, no. 3 (2010): 805-39].

53. Fournier et al., 143 .

54. "In these referendums, both elite signals and media attention were lacking ... politicians ignored the issue. Many parties did not take a position and those who did were not campaigning vigorously on it...the mass media simply followed suit” (Fournier et al., 144).

55. That is why deliberative polls and other practices to promote deliberation in initiative campaigns, as distinct from ordinary campaigns, should be encouraged. The objections raised here against deliberative campaigns, which cast doubt on some uses of Fishkin's deliberative polls, do not apply to the more promising uses in initiative campaigns and practices of popular constitutionalism. See James Fishkin, "Deliberation by the People Themselves: Entry Points for the Public Voice," section entitled “Connecting Deliberative to Participatory Democracy," paper presented at the Symposium on the Law of Deliberative Democracy, Straus Institute for the 
Advanced Study of Law and Justice, New York University, April 5-6, 2013. For some examples and proposals for improving initiative campaigns (many of which go beyond electoral reform as such), see John Gastil, Justin Reedy and Chris Wells, "When Good Voters Make Bad Policies: Assessing and Improving the Deliberative Quality of Initiative Elections," University of Colorado Law Review 78 (Fall 2007): 135-88.

56. For experience in European countries, see Maija Setala and Theo Schiller, eds., Citizens' Initiatives in Europe: Procedures and Consequences of Agenda (New York: Palgrave Macmillan, 2012).

57. In nearly all democracies the procedures that govern elections have been established by officials or representatives themselves: David M. Farrell, Electoral Systems (New York: Palgrave. 2001), 176-81; and Denis Pilon, Renewing Canadian Democracy: Citizen Engagement in Voting System Reform (Law Commission of Canada/Fair Vote Canada, York University, March 2002). 